\title{
IMPACT OF $\mathrm{CO}_{2}$ CONCENTRATION AND AMBIENT CONDITIONS ON MICROALGAL GROWTH AND NUTRIENT REMOVAL FROM WASTEWATER BY A PHOTOBIOREACTOR
}

Almomani, F. ${ }^{*}$, Al Ketife, A.M.D ${ }^{2}$., Judd, $\mathrm{S}^{2,3}$., Shurair, $\mathrm{M}^{1}$., Bhosale, R. ${ }^{1}$, Znad, H. ${ }^{4}$ and Tawalbeh, M. ${ }^{5}$

1) Department of Chemical Engineering, Qatar University, P.O box 2713, Doha, Qatar;

2) Gas Processing Center, Qatar University, P.O box 2713, Doha, Qatar;

3) Cranfield Water Science Institute, Cranfield University

4) Department of Chemical Engineering, Curtin University, GPO Box U 1987 Perth WA 6845, Australia.

5) Sustainable \& Renewable Energy Engineering Department, College of Engineering, University of Sharjah, P.O Box 27272 Sharjah, UAE

\begin{abstract}
The increase in atmospheric $\mathrm{CO}_{2}$ concentration and the release of nutrients from wastewater treatment plants (WWTPs) are environmental issues linked to several impacts on ecosystems. Numerous technologies have been employed to resolves these issues, nonetheless, the cost and sustainability are still a concern. Recently, the use of microalgae appears as a cost-effective and sustainable solution because they can effectively uptake $\mathrm{CO}_{2}$ and nutrients resulting in biomass production that can be processed into valuable products. In this study single (Spirulina platensis $(S P . P L)$ and mixed indigenous microalgae (MIMA) strains were employed, over a 20-month period, for simultaneous removal of $\mathrm{CO}_{2}$ from flue gases and nutrient from wastewater under ambient conditions of solar irradiation and temperature. The study was performed at a pilot scale photo-bioreactor and the effect of feed $\mathrm{CO}_{2}$ gas concentration in the range $(2.5-20 \%)$ on microalgae growth and biomass production, carbon dioxide bio-fixation rate, and the removal of nutrients and organic matters from wastewater was assessed. The MIMA culture performed significantly better than the monoculture, especially with respect to growth and $\mathrm{CO}_{2}$ bio-fixation, during the mild season; against this, the performance was comparable during the hot season. Optimum performance was observed at $10 \% \mathrm{CO}_{2}$ feed gas concentration, though MIMA was more temperature and $\mathrm{CO}_{2}$ concentration sensitive. $M I M A$ also provided greater removal of $\mathrm{COD}$ and nutrients $(\sim 83 \%$ and $>99 \%)$ than SP.PL under all conditions studied. The high biomass productivities and carbon bio-fixation rates $\left(0.796-0.950 \mathrm{~g}_{\mathrm{dw}} \cdot \mathrm{L}^{-1} \cdot \mathrm{d}^{-1}\right.$ and $0.542-1.075 \mathrm{~g}_{\mathrm{C}} \cdot \mathrm{L}^{-1} \cdot \mathrm{d}^{-1}$ contribute to the economic sustainability of microalgae as $\mathrm{CO}_{2}$ removal process. Consideration of operational energy revealed that there is a significant energy benefit from cooling to sustain the highest productivities on the basis of operating energy alone, particularly if the indigenous culture is used.
\end{abstract}

Keywords: Nutrient removal, growth rate, biomass production, carbon capture, energy balance.

\section{Introduction}

There has been increasing focus on the use of microalgal culture technology (MCT) for both bio-fixation of $\mathrm{CO}_{2}$ from flue gases (Adamczyk et al., 2016; Al Ketife et al., 2017; Almomani et al., 2017; Razzak et al., 2013; Toledo-Cervantes et al., 2018; Zhou et al., 2017a;

\footnotetext{
*Corresponding author: Fares Almomani, Professor, College of Engineering, Department of Chemical Engineering, Qatar University, P. O. Box 2713, Doha, Qatar. Tel: +974 44034140 Fax: +974 4403 4131. E-mail:

falmomani@qu.edu.qa
} 
Zhou et al., 2017b) and removal of nutrients from wastewater (AlMomani and Örmeci, 2016; Arbib et al., 2017; Gao et al., 2018; Sutherland et al., 2014; Sutherland et al., 2015; Zhou et al., 2017a; Znad et al., 2018a), with the technical and cost implications of the combined process also recently considered (Judd et al., 2017; Kasprzyk and Gajewska, 2019). The use of biology for carbon capture and direct generation of useful products, predominantly biofuel (Bai and Acharya, 2017; de Godos et al., 2014; Fernández et al., 2012; Kassim and Meng, 2017; Singh et al., 2016; Zhang et al., 2011), obviates the energy-intensive solvent regeneration step of the conventional absorption process for carbon capture (Hammond and Spargo, 2014; Wang et al., 2017; Wilberforce et al., 2019). Moreover, the removal of nutrients from wastewater is considered an essential requirement for the approval of treatment facilities (Almomani et al., 2014; Nourmohammadi et al., 2013). Nutrients in wastewater leads to eutrophication (Blaas and Kroeze, 2014; Schneider et al., 2013), increases the growth of unwanted plants and poses a more toxic environment to fish and aquatic organisms (Allagui et al., 2014; Anis et al., 2015; Kang et al., 2019; Liang, 2009; Ziegler et al., 2016). It has been proven that untreated nutrients in wastewater run-offs hinder the efficiency of disinfection processes and increase the chlorine demand (Farrell et al., 2018; Martin et al., 1985). As a result, it has become necessary to find a successful treatment process that can remove nutrients before the discharge of treated wastewater. MCT offers a single-step alternative to classical biological nutrient removal (BNR) technologies for wastewater treatment (Judd et al., 2015), which are generally simple and effective for removal of nitrogen $(\mathrm{N})$ but more complex for phosphorus $(\mathrm{P})$ removal.

MCT thus provides a potentially low-energy means of achieving both carbon capture and nutrient removal in a single process (Cabello et al., 2017; Wang et al., 2018). However, the economic viability of the process is highly sensitive to the rate of $\mathrm{CO}_{2}$ fixation, in $\mathrm{CO}_{2}$ mass per day captured per unit of volume of biomass, and the corresponding algal growth rate. Published works on the use of MTC have thus far predominantly been at the bench scale, for short time and using artificial light during cultivation periods (Abou-Shanab et al., 2013; Abreu et al., 2012; Al Ketife et al., 2017; AlMomani and Örmeci, 2016; Marbelia et al., 2014; Znad et al., 2018a). Published works that deal with algae growth under natural solar irradiation are limited and in most cases deal with carbon capture (Lam and Lee, 2014; Li et al., 2013) or nutrient removals (Sutherland et al., 2014; Zhimiao et al., 2016) individually, the latter mainly relating to biofuel production (Do et al., 2018). Moreover, based on our literature review, no work was published on the cultivation and use of microalgae in single process for carbon capture and nutrient removal under the prevailing favorable ambient conditions of the Arabian Gulf, where natural light levels are high and wastewater temperatures predominantly in the $20-30^{\circ} \mathrm{C}$ range known to favor algal growth (Bouterfas et al., 2002). Moreover, few such studies encompassed a comparison of different microalgae strains to improve the performance of the MTC process.

Accordingly, the current study addresses the above-identified knowledge gaps, in terms of evaluating the potential use of microalgae as MTC technology for simultaneous removal of $\mathrm{CO}_{2}$ and nutrient under different seasonal conditions and for an extended time. The work was conducted at pilot scale for a period of 20 months, during this time $\mathrm{CO}_{2}$ bio-fixation capacity and growth of two algal strains (single strain Spirulina platensis (SP.PL) and mixed indigenous microalgae (MIMA)) and concomitant removals (nutrients and organic matter )from wastewater were studied. The seasonally affected algal growth, $\mathrm{CO}_{2}$ bio-fixation, and nutrient removal rates were then used to assess the overall energy benefit or penalty of maintaining the optimum temperature during the mild season. The appraisal was limited to determining the difference in 
energy capacity between the hot and mid seasons, all other energy contributions (pumping, mixing, etc) being considered unchanged between seasons.

\section{Materials and methods \\ $2.1 \quad$ Algal culture}

Both a single-strain microalgae species (Spirulina platensis, SP.PL, UTEX Culture Collection of Algae, University of Texas) and a mixed indigenous microalgae (MIMA) culture were used in the study. The MIMA was collected from a secondary basin of Doha South wastewater treatment plant (WwTP), and was washed thoroughly with distilled water to remove residual bacteria prior to cultivation without further characterization. Stock solutions of the microalgae were grown at room temperature under continuous fluorescent light providing an irradiance of $180 \mu \mathrm{E} \cdot \mathrm{m}^{-2} \cdot \mathrm{s}^{-1}$, and mixed by aeration with filtered air. The growth media was informed by Zarrouk (1966) and comprised (in g/L): $16.8 \mathrm{NaHCO}_{3}, 2.5 \mathrm{NaNO}_{3}, 0.5 \mathrm{~K}_{2} \mathrm{HPO}_{4}, 1$ $\mathrm{K}_{2} \mathrm{SO}_{4}, 1 \mathrm{NaCl}, 0.2 \mathrm{MgSO}_{4} .7 \mathrm{H}_{2} \mathrm{O}, 0.04 \mathrm{CaCl}_{2} .2 \mathrm{H}_{2} \mathrm{O}, 0.01 \mathrm{FeSO}_{4} .7 \mathrm{H}_{2} \mathrm{O}$ and 0.08 EDTA, yielding a $\mathrm{pH}$ of $9.5 \pm 0.4$. The required $\mathrm{pH}$ values for $S P . P L$ and $M I M A$ are $9.5 \pm 0.4$ and $7.5 \pm 0$, respectively. The $\mathrm{pH}$ of the medium was adjusted as required with $1 \mathrm{M}$ solutions of $\mathrm{NaOH}$ or $\mathrm{HCl}$.

The carbon content of microalgae biomass was determined using a Flash EA1112 CHNS analyzer (Thermo Finnigan CE Instruments, Italy) equipped with a gas chromatography column and a thermal conductivity detector. Algae samples were incinerated under controlled conditions, followed by catalytic oxidation and reduction. The gases generated were separated by gas chromatography and measured with a thermal conduction detector (TCD). Tests were performed following the methodology described previously (Gonçalves et al., 2016).

\section{$2.2 \quad$ Pilot plant photobioreactor design}

The 250L-capacity PBR pilot plant (Greenline, Valorsabio, Santa Cruz, Portugal) was configured as eight, $100 \mathrm{~mm}$-diameter high-grade polyethyl terephthalate columns operating in series (Fig. 1). The tubes were interconnected by collectors at both ends and individually fitted with $\mathrm{CO}_{2}$ gas injection ports and sampling points. $\mathrm{pH}$, temperature and dissolved oxygen (DO) sensors were fitted at the outlets of tubes 1,4 and 8 , and connected to a data-logger. The algal biomass was circulated with a variable speed pump, and the return water blended with fresh feed in a separate $10 \mathrm{~L}$ mixing tank. The algal biomass was recovered using a simple clarifier coupled with a membrane separation unit. The plant was installed at the Qatar University campus in Doha $\left(25.2854^{\circ} \mathrm{N}, 51.5310^{\circ} \mathrm{E}\right)$ in a partially shaded area.

\subsection{Pilot plant operation}

Trials were conducted over a period of 20 months (May 2016 - Dec 2017) under ambient conditions of light and temperature. The wastewater used (Table 1) was secondary wastewater from Doha North WwTP. Experimental conditions were recorded four times daily and segregated according to quarterly time periods; Period \#1; Jan-Mar, Period \#2; Apr-Jun, Period \# 3; Jul-Sep and Period \#4; Oct-Dec. The operational periods are characterized by ambient temperature $\left(T_{A},{ }^{\circ} \mathrm{C}\right)$, PBR pilot plant temperatures $\left(T_{B},{ }^{\circ} \mathrm{C}\right)$, number of hours of daylight $(\tau, \mathrm{h})$, light intensity $\left(I_{\text {avease }}, \mu \mathrm{E} \cdot \mathrm{m}^{-2} \mathrm{~s}^{-1}\right)$ and total light received $\left(I_{\text {ave }}^{\prime}, \mathrm{E} \cdot \mathrm{m}^{-2}\right)$. Table 2 shows the maximum, minimum and average key operating parameters $\left(T_{A}, T_{B}, \tau, I\right.$ and $\left.I^{\prime}\right)$ during the operation periods of the PBR. The averages light intensities were determined as the mean of daily measurements recorded over the stated periods. At least four $I$ measurements were carried 
out in each day using NIST Radiometer (International light. Model IL 400A). Measurements were taken at the surface of polyethyl terephthalate columns and reported an average value at $95 \%$ confidence level $(\alpha=5 \%) . T_{A}, T_{B}$, and $\mathrm{pH}$ were measured continuously using electrodes and thermometers connected to data-logger and reported as an average value at $\alpha=5 \%$. Under all studied conditions, it was observed that the $T_{B, \text { ave }}$ is $1-3.7^{\circ} \mathrm{C}$ lower than $T_{A, \text { avg. }}$. The ambient temperature.

Commissioning proceeded by circulating the secondary effluent through the reactor for one hour before adding $7.5 \mathrm{~L}$ of the algal inoculation media. Cultures were allowed to grow for seven days at (i) initial biomass (cell dry weight) concentration of $4.4 \times 10^{-3}$ gDw.L $\mathrm{L}^{-1}$, (ii) an initial $\mathrm{pH}$ of $9.5 \pm 0.4$ and $7.5 \pm 0$ for $S P . P L$ and $M I M A$, respectively, and (iii) ambient temperatures and light intensity corresponding to cultivation period $\tau$. The algae cultures were pre-adapted at a $\mathrm{CO}_{2}$ feed gas concentration $\left(C_{c, g}\right)$ of $2.5 \% \mathrm{v} / \mathrm{v}$ to overcome the environmental stress induced by the higher $\mathrm{CO}_{2}$ dosages (5-20\%) during startup.

At the end of the seventh day, the pilot plant was filled with fresh secondary effluent WW. The wastewater was circulated inside the reactor for one hour and the biomass concentration inside the pilot plant was adjusted to $0.012 \pm 0.02 \mathrm{~g}_{\mathrm{dw}} \cdot \mathrm{L}^{-1}$ by adding $7.5 \mathrm{~L}$ of concentrated algae before starting the reactor operation. The effluent was then replaced with a fresh sample and $\mathrm{CO}_{2}$-enriched air injected into the base of the reactor tubes at concentrations of $2.5-20 \% \mathrm{v} / \mathrm{v}$ and a normalized flow rate of $0.4 \mathrm{vvm}$ (volume of gas per working volume per minute) divided equally between all eight cylinders. The $\mathrm{CO}_{2}$ concentrations were obtained by mixing atmospheric air with $\mathrm{CO}_{2}$ at proportions informed by mass flow meters (RS Components, Madrid, Spain), and the gas stream $0.22 \mu \mathrm{m}$-filtered prior to daily injection. As the main objective of this study is to utilize MCT for bio-fixation of $\mathrm{CO}_{2}$ from flue gases, analysis of flue gas samples from local industries showed $\mathrm{CO}_{2}$ concentrations in the range 4 to $17 \% \mathrm{v} / \mathrm{v}$. Accordingly, it was decided to use in this study $\mathrm{CO}_{2}$ concentrations in the range of 2.5 to $20 \%$ and investigate if microalgae can tolerate concentrations similar to that in flue gases or higher. Samples were collected daily for determination of algal growth rate, organic matter and nutrient percentage removals, biomass productivity and $\mathrm{CO}_{2}$ bio-fixation rate. $\mathrm{pH}$ and $\mathrm{CO}_{2}$ partial pressure were continuously monitored over the course of the experiments using sensors.

\section{$2.4 \quad$ Analyses}

Algal growth was determined by measuring the increase of the growth medium optical density at $690 \mathrm{~nm}\left(\mathrm{OD}_{690}\right)$ (Almomani and Örmeci, 2018). Samples were collected daily from the PBR equalization tank for $\mathrm{OD}_{690}$ determination using a spectrophotometer (VARIAN 100 Bio UV-visible spectrophotometer, USA). The measured OD $\left(\mathrm{OD}_{690}\right)$ was converted to biomass concentration $\left(X, \mathrm{~g}_{\mathrm{dw}}\right.$. $\left.\mathrm{L}^{-1}\right)$ according to the calibration curve:

$$
X=0.652 . O D_{690 \mathrm{~nm}}-0.0021
$$

The specific growth rates $\left(\mu, \mathrm{d}^{-1}\right)$ and biomass productivities $\left(P_{b i o}, \mathrm{~g}_{\mathrm{dw}} \mathrm{L}^{-1} \mathrm{~d}^{-1}\right)$ were then determined according to:

$$
\mu\left(\text { day }^{-1}\right)=\frac{\ln \left(X_{2}\right)-\ln \left(X_{1}\right)}{\Delta t}
$$

where $X_{1}$ and $X_{2}$ represent the initial and final biomass concentration (in $\mathrm{g}_{\mathrm{dw}} \mathrm{L}^{-1}$ ) over the time period $\Delta t$ (in days) of the initial period of the exponential growth phase.

$$
P_{b i o}\left(\mathrm{~g}_{\mathrm{dw}} \cdot \mathrm{L}^{-1} \mathrm{~d}^{-1}\right)=\frac{X_{f}-X_{i}}{t_{f}-t_{i}}
$$

where $X_{f}$ and $X_{i}$ correspond to biomass concentration (in $\mathrm{g}_{\mathrm{dw}}$. $\mathrm{L}^{-1}$ ) at times $t_{f}$ and $t_{i}$ (in days), these being the end and beginning of cultivation time respectively. 


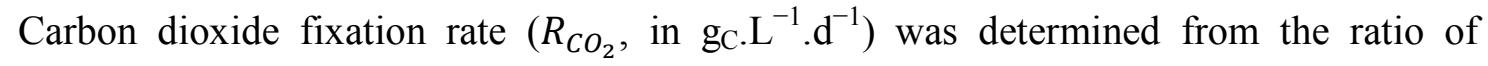
microalgae carbon content to average biomass productivities:

$$
R_{\mathrm{CO}_{2}}=C_{C} \cdot P_{b i o} \cdot \frac{\mathrm{M}_{\mathrm{CO}_{2}}}{\mathrm{M}_{\mathrm{c}}}
$$

where $C_{C}$ is the carbon content of the microalgal biomass (in \% w/w) determined using the Flash CHNS analyzer, $P_{\text {bio }}$ the average biomass productivity, and $\mathrm{M}_{\mathrm{CO} 2}$ and $\mathrm{M}_{\mathrm{C}}$ the respective $\mathrm{CO}_{2}$ and carbon molecular weights $\left(\mathrm{g} \cdot \mathrm{mol}^{-1}\right)$.

\section{$2.5 \quad$ Net energy penalty/benefit determination}

Significant energy dissipation takes place in the cultivation process from water evaporation and convection from air bubbles. The determination of the benefit or penalty of cooling the system during the hot season can be achieved if a few simplifying assumptions are made, specifically:

a. losses due to minor differences in temperature between water PBR and water vapor in the air near the liquid surface can be neglected, such that radiation can be ignored,

b. the water vapor temperature is the same as that of air in the PBR enclosure,

c. all other energy contributors (mechanical mixing, liquid and biomass transfer, etc) are unaltered.

The evaporative heat loss $W_{E V}\left(\mathrm{~kJ} \cdot \mathrm{h}^{-1}\right)$ is then given by:

$$
W_{E V}=\Delta H_{V} \times R_{E V}
$$

where $\Delta H_{V}$ is the heat of evaporation in $\mathrm{kJ} \cdot \mathrm{kg}^{-1}$ and $R_{E V}$ is the water evaporation rate in $\mathrm{kg} \cdot \mathrm{h}^{-1}$, estimated from(Rafferty and Culver, 1998):

$$
R_{E V}=0.00753 \times A \times\left(P_{W}-P_{A}\right)
$$

$P_{w}, P_{A}$ in the above equation respectively represent the saturated water vapour and dew point pressure (in $\mathrm{mmHg}$ ), and $A$ is the surface area of the PBR.

The convective heat loss $W_{C}$ in $\mathrm{kJ} . \mathrm{h}^{-1}$ is given by:

$$
W_{C}=h_{c} \times A \times\left[T_{w}-T_{a}\right]
$$

where $T_{w}$ and $T_{A}$ are the water and air temperature respectively and $h_{c}$ the heat transfer coefficient in W.m ${ }^{-2}$ which can be estimated from (Stoever, 1941):

$$
h_{c}=5.7+3.8 v
$$

where $v$ is the air speed in $\mathrm{m} \mathrm{s}^{-1}$.

The heat transferred over the whole cultivation period is thus given by $W_{E V}+W_{C}$. This energy transfer is then balanced against the potential energy of the generated biofuel over the same period, a conversion factor of $7.55 \mathrm{kWh}$ per $\mathrm{kg}$ algal biomass (Beal et al., 2012) being used to convert from $\mathrm{kg}_{\mathrm{DW}}$ biomass to $\mathrm{kWh}$ potential energy.

\section{Results and discussion}

\subsection{Algae growth and productivity \\ 3.1.1 Seasonal impacts}

Examples of growth of SP.PL and MIMA during the four cultivation periods are given in Fig. 2 for the reference feed gas concentration $C_{c, g}=2.5 \% \mathrm{CO}_{2}$. Both algae strains followed the typical growth curve of lag, exponential growth, and stationary phases. The lag time for SP.PL was longer than MIMA and for both algae the lag phase highly dependent on cultivation period. For SP.PL lag phase durations of 1.5, 0.75, 1.75 and $1.25 \mathrm{~d}$ were observed for Periods \#1-4 respectively, compared with shorter lag phases $(\sim 0.25-0.5 \mathrm{~d})$ for $M I M A$ cultures for all periods. The subsequent exponential growth phase differed less consistently between the two algal 
strains, the durations during Periods \#1-4 being 5.5, 3.5, 3.3 and $9.5 \mathrm{~d}$ for SP.PL and 4.0, 4.0, 3.5 and $4.25 \mathrm{~d}$ for $M I M A$ respectively. The short lag-phase for MIMA reflected the expected increased tolerance of the locally-acclimatized mixed culture to changes in conditions.

At the same feed gas concentration $C_{c, g}$ of $2.5 \% \mathrm{CO}_{2}$, the $\mu$ values, as determined during the first three days of the exponential growth phase, and biomass productivity were found to vary significantly with the season for both algal strains (Fig. 3a). The most rapid growth and productivity $\left(P_{b i o}\right)$ was recorded at the mild temperatures $\left(20-25^{\circ} \mathrm{C}\right)$ and moderate total light intensities $\left(I_{\text {ave }}^{\prime}=4.64-8.47\right.$ E. $\left.\mathrm{m}^{-2}\right)$ associated with Periods $\# 1$ and $\# 4$. The $5^{\circ} \mathrm{C}$ lower temperature of Period \#1 only marginally reduced $P_{\text {bio }}$ compared with Period $\# 4$, whereas the $5^{\circ} \mathrm{C}$ increase in bioreactor temperature (from 25 to $30^{\circ} \mathrm{C}$ ), and accompanying $4 \%$ increase in received irradiation dose (Table 2), produced a 30-50\% drop in growth rate between Periods \#4 and \#2. Growth was correspondingly up to $20 \%$ higher for the MIMA strain for Periods \#1 and $\# 4$, compared with a small difference for Periods \#2 and \#3 (Fig. 3a). This to some extent corroborates previous reports of major biomass loss from exceeding the optimum temperature by only $2-4^{\circ} \mathrm{C}$ (Moheimani and Borowitzka, 2007; Singh and Dhar, 2011), and very low growth rates reported at temperatures higher than $35^{\circ} \mathrm{C}$ (Teoh et al., 2004) which some authors have attributed to the reduced $\mathrm{CO}_{2}$ solubility in the liquid which affects the available inorganic carbon and the growth (Lam and Lee, 2013). A similar trend with the season was noted at higher $C_{c, g}$ values (Figs. 3b-d).

Reported values of $\mu$ in the literature have ranged from 0.22 and $0.41 \mathrm{~d}^{-1}$ for light intensity (I) values between 68 and $85 \mu \mathrm{E} . \mathrm{m}^{-2} . \mathrm{s}^{-1}$ (Kumari et al., 2014; Singh et al., 2016; Sydney et al., 2010) and as high as $1.4 \mathrm{~d}^{-1}$ at intensity of $174 \mu \mathrm{E} \cdot \mathrm{m}^{-2} \cdot \mathrm{s}^{-1}$ (Xue et al., 2011). Many studies of microalgae generally have demonstrated that increasing the light intensity beyond the socalled saturation point, the maximum light intensity the algal biomass is able to harness (Richmond, 1999), may lead to photo-oxidation that damage the light receptors and so impair photosynthesis and algal productivity (Brock and Brock, 1969; Ota et al., 2015; Singh and Singh, 2015). In the present study, although the mean light intensity values at the PBR surface almost doubled from 115 to $220 \mu \mathrm{E} . \mathrm{m}^{-2} . \mathrm{s}^{-1}$ in Periods \#1 and \#4 respectively, the growth rates increased only by $18 \%$ and $16 \%$ for SP.PL and MIMA, respectively. Light intensities providing a reasonable specific growth rate $(\mu)$ and biomass productivity $\left(P_{b i o}\right)$ reported for Chlorella vulgaris (C.V), the most commonly studied strain, varied widely at $40-1240 \mu \mathrm{E} \cdot \mathrm{m}^{-2} . \mathrm{s}^{-1}$ (AbouShanab et al., 2013; Abreu et al., 2012; AlMomani and Örmeci, 2016; Lam and Lee, 2013; Li et al., 2003; Marbelia et al., 2014; Ruiz-Martinez et al., 2012; Znad et al., 2018a). According to the $C . V$ literature at an optimum light intensity of $100 \mu \mathrm{E} \cdot \mathrm{m}^{-2} \cdot \mathrm{s}^{-1}$ and $5 \% C_{c, g}$, the associated maximum $\mu$, and $P_{b i o}$ values are around $1.17 \mathrm{~d}^{-1}$ and $0.74 \mathrm{~g} . \mathrm{L}^{-1} \cdot \mathrm{d}^{-1}$ respectively at a temperature of $24^{\circ} \mathrm{C}$ for a batch cultivation process (Abreu et al., 2012; Al Ketife et al., 2017; Li et al., 2013). This compares to a reasonable growth rate at a narrower range of $68-400 \mu \mathrm{E} . \mathrm{m}^{-2} . \mathrm{s}^{-1}$ for $S P . P L$ (Ho et al., 2018; Kumari et al., 2014; Liu et al., 2018; Singh et al., 2016; Xue et al., 2011; Yuan et al., 2011; Zhou et al., 2017b).

It has been noted that the simple organic matter in municipal effluent generally provides more rapid growth than a $\mathrm{CO}_{2}$ carbon source alone, due to mixotrophic growth (Znad et al., 2018a). Nonetheless, the maximum $\mu$ values recorded in the current study were somewhat higher than those reported under similar conditions for $C . V$. For example, $\mu$ values for $C . V$ cultivated in secondary wastewater $(\mathrm{SWW})$ have previously been reported as between 0.186 and $1.86 \mathrm{~d}^{-1}$ (AlMomani and Örmeci, 2016; Ruiz-Martinez et al., 2012; Znad et al., 2018a; Znad et al., 2018b). 


\subsubsection{Feed gas $\mathrm{CO}_{2}$ concentration impacts}

Changes in growth and productivity were evident across the feed gas $\mathrm{CO}_{2}$ concentration range studied (Figs. 3a-d). Over the $2.5-20 \%$ range of $C_{c, g}$ values studied there was a maximum in both $P_{b i o}$ and $R_{C O 2}$ at $10-15 \%$ (Fig. 4) across all seasons. The SP.PL trend indicated a clear maximum $R_{\mathrm{CO} 2}$ for Period \#4 at $C_{c, g}=10 \%$, whereas the maximum for Periods \#1, \#2 and \#3 occurred at around $15 \%$. For MIMA the maximum $R_{\mathrm{CO} 2}$ for periods $\# 2$ and $\# 4$ was at $10 \%$, and for Periods \#1 and \#3 at $15 \%$. Values of $R_{\mathrm{CO} 2}$ increased by $35-42 \%$ by increasing $C_{c, g}$ from 2.5 to $10 \% \mathrm{v} / \mathrm{v}$ across all seasons.

The overall trend suggests growth may be carbon limited at the lower gas concentration but inhibited (though still reasonably high) at elevated $\mathrm{CO}_{2}$ levels, since across all $C_{c, g}$ values the algae carbon content changed little (from $41.5 \pm 1.2$ to $51.5 \pm 2.1 \% \mathrm{w} / \mathrm{w}$ for $S P . P L$, and from $44.2 \pm 1.3$ to $56.2 \pm 3.1 \% \mathrm{w} / \mathrm{w}$ for $M I M A$ ). As with the growth data (Fig. 3), seasonal impacts are significant with reference both to the optimum values and the trend. As indicated in Figure 3, $P_{b i o}$ is increased by $42 \%$ by an increase in $C_{c, g}$ from 2.5 to $10 \% \mathrm{v} / \mathrm{v}$ for all seasons. However, the extent of the fall in $P_{b i o}$ and $R_{\mathrm{CO}}$ beyond the optimum concentration also appears to be season dependent, with a greater rate of decline during Period \#3 (the hot season, represented be the dashed lines in Fig. 4) than Period \#4 (the mild season) for the MIMA strain in particular. The results are comparable to values reported in the literature (Gonçalves et al., 2016; Tang et al., 2011)

The decreased bio-fixation efficiency at higher $C_{c, g}$ values has been attributed to diminution of the photosynthetic action of the selected microorganisms (Al Ketife et al., 2016; Znad et al., 2018b) as a consequence of the reduced $\mathrm{pH}$ and $\mathrm{CO}_{2}$ mass transfer, the latter pertaining to the relatively slow rate of hydrolysis of $\mathrm{CO}_{2}$ to $\mathrm{H}_{2} \mathrm{CO}_{3}$ (Silva and Pirt, 1984; Sung et al., 1999). In the current study the introduction of $\mathrm{CO}_{2}$ temporarily marginally depressed the $\mathrm{pH}$, to $8.2 \pm 0.1$ for $S P . P L$ and $6.8 \pm 0.2$ for $M I M A$, with recovery to the normal operational range of 8.6-9.6 (8.9 0.2 on average) and 6.8-7.5 (7.2 \pm 0.1 on average) for the two respective cultures taking up to $7 \mathrm{hrs}$. Notwithstanding this, and as with the growth data, the carbon bio-fixation values reported in this study are slightly higher than the values reported in the literature for the C.V. strain (Ruiz-Martinez et al. 2012, Li et al. 2013).

\subsection{Organic carbon and nutrient removal}

Examples of organic carbon and nutrient removal trends for SP.PL (Fig. 5a) and MIMA (Fig. 5b) for Periods \#3 and \#4, respectively representing the hot and mild seasons, mirror the trends in growth and productivity. Percentage removals of organic carbon (as chemical oxygen demand, COD), total inorganic nitrogen (TIN) and total phosphorus (TP) gradually decreased over the first 3-10 days of cultivation to reach an equilibrium value. Equilibration was most rapid for phosphate ( 3 days) followed by ammonia ( 5 days), COD taking around 10 days to reach the maximum removal value. The equilibrium effluent TIN species (ammonia, nitrate and nitrite) concentrations ranged from 0 to $7.3 \pm 0.1 \mathrm{mgN} \mathrm{L}^{-1}$, and those of TP from 0 to $3.0 \pm 0.1 \mathrm{mg} \mathrm{L}^{-1}$. Control experiments were conducted to measure the degree of ammonia removal by volatilization at working $\mathrm{pH}$ values. The results reveal that the percentages of ammonia removals due to volatilization at $\mathrm{pH}$ of $8.9 \pm 0.2$ and $7.57 .2 \pm 0.1$ were $6 \%$ and $2 \%$, respectively, confirming that the observed ammonia removals were due to the microalgae uptake. Temperature and $\mathrm{pH}$ fluctuated around an average value with no noticeable increase or decrease over the course of the tests conducted within a specific period apart from a brief decrease during 
the daily injection of $\mathrm{CO}_{2}$. Dissolved oxygen (DO) values throughout the study ranged from 7.6 \pm 0.1 to $8.6 \pm 0.1 \mathrm{mg} . \mathrm{L}^{-1}$, which was not considered sufficiently high to cause photosynthesis inhibition. There was no statistically significant difference between the three measuring locations of DO confirming that the growth, $\mathrm{CO}_{2}$ capturing and contaminates removals are homogenous all over the PBR. Moreover, it was observed the average DO values for periods \# 2, 3 and 4 are within 95 to $98 \%$ of the corresponding oxygen-water saturated values. Period \#1 showed DO value of $92 \%$ of the saturation limit.

A control experiment conducted in the absence of the algal biomass indicated less than $4 \%$ and 3\% COD and ammonia removals. It was thus surmised that most of the observed ammonia and organic carbon removal was by algae assimilation.

Trends in equilibrium carbon and nutrient removal with $C_{c, g}$ followed those of the growth, productivity and bio-fixation, peaking at $10 \%$ for all algal and wastewater species under all ambient conditions, other than for COD and TP removal by MIMA during the mild season (Periods \#1 and \#4) when removal peaked at 15\% feed gas concentration (Fig. 5). For both strains, COD removal decreased during the hot season of Periods \#2 and \#3, ranging from 47 to $60 \%$ for SP.PL compared with $71-90 \%$ during Periods \#1 and \#4. The corresponding values for MIMA were in the range $59-70 \%$ for Periods \#2 and \#3 and $77-99 \%$ for Periods \#1 and \#4. TIN and TP followed the same trends as COD removal and were removed to roughly the same extent for a specific set of operating conditions. TIN removal by SP.PL, for example, decreased from 70-93\% during Periods \#1 and \#4 to 49-59\% during Periods \#2 and \#3.

Whilst some authors have reported negligible removal of COD by algae (Wang et al., 2009), the application of SP.PL to wastewater purification generally has been widely studied (Table 3). Across a number of studies, Li et al. 2013, AlMomani and Örmeci 2016, Znad et al. 2018 showed average removals of COD, TN and TP from municipal primary and secondary wastewater ( $\mathrm{PWw}$ and $\mathrm{SWw}$ respectively) have varied between 22 and 95\%. The wide variation is associated largely with key factors such as incubation time, temperature and algal species. The outcomes also again reflect the impact of mixotrophic rather than autotrophic growth, i.e. the energetic preference for dissolved organic carbon assimilation compared with $\mathrm{CO}_{2}$ fixation (Lalucat et al., 1984), as dictated by photo-limitation during periods of darkness (Hatnagar et al., 2010).

\subsection{Energy balance}

Whilst the productivity of the PBR is reasonable during the hot season under optimal conditions of $10 \% \mathrm{CO}_{2}$ feed gas concentration, the maximum $P_{\text {bio }}$ value attainable under the mild season conditions is around $80 \%$ higher for the $M I M A$ culture. This being the case, the option of implementing cooling for the PBR during the hot season should be considered.

A very simple approach can be taken to estimate the energy benefit or penalty on implementing cooling based on two assumptions:

a. The improved productivity during the mild season is primarily associated with the lower temperatures, and

b. Productivity is considered roughly linearly related to solar irradiation intensity.

Any error associated with the second assumption is likely to be small if the benchmark data used for the comparison are the mean values for Periods \#2 and \#3 (hot season) and those of Period \#4 (mild season). The average value of $I_{\text {ave }}$ ' for Period \#2-3 is 9.4 E. . $^{-2}$, compared with a value of 8.47 for Period \#4 - a difference of only 10\%. Moreover, data from Period \#1 suggest that light intensity is not a significant contributory factor, given that mean productivity is only 
$\sim 20 \%$ less than the maximum value associated with Period \#4 despite having an $I_{\text {ave }}$ value little more than half that of Period \#4. There is thus a maximum possible error of $10 \%$ from the second assumption.

The calculation proceeds by making basic assumptions concerning the prospective biofuel content of the culture, and the associated energy, and the energy demanded for chilling the culture as given by $W_{E V}$ and $W_{C}$ (Section 2.5). Accordingly, based on Equations 4 and 5, the PBR configuration described in Section 2.2, and the seasonal ambient conditions summarised in Table 2, values for $W_{E V}$ and $W_{C}$ of 0.92 and $0.10 \mathrm{kWh} \cdot \mathrm{m}^{-3}$ culture for the cultivation period can be calculated for the cooling energy requirement. This compares with a value of 4.6 and $5.4 \mathrm{kWh} . \mathrm{m}^{-}$ ${ }^{3}$ for the latent biomass energy for the SP.PL and MIMA cultures respectively. Thus, even when an electrical: cooling power conversion efficiency of $50 \%$, the option of cooling the culture during the hot season results in a $2.6-4.4 \mathrm{kWh} . \mathrm{m}^{-3}$ net increase in recovered energy overall.

\section{Conclusions}

An extended, 20-month study of two algal species, a monoculture (Spirulina platensis, $S P . P L)$ and mixed indigenous culture (MIMA), in microalgae culture technology (MCT) configured as a photobioreactor (PBR) has been undertaken. The study was conducted at pilotscale using a 60 L-capacity column reactor installed outdoors in the Arabian Gulf and subject to uncontrolled ambient conditions of light and temperature. PBR performance was appraised with reference to the dual functions of $\mathrm{CO}_{2}$ mitigation by bio-fixation (and the associated algal growth) and wastewater treatment, the latter with reference to the 'key wastewater quality components of chemical oxygen demand (COD), the nutrient content as represented by the total nitrogen $(\mathrm{TN})$, and total phosphorus (TP). The reactor was fed with secondary municipal wastewater ( $\mathrm{SWw}$ ) and a gas stream having $\mathrm{CO}_{2}$ concentrations $\left(C_{c, g}\right)$ between 0 and $20 \%$. Accordingly, the following outcomes were obtained:

1. The mixed indigenous culture performed significantly better than the monoculture, especially with respect to growth and $\mathrm{CO}_{2}$ bio-fixation, during the mild season; against this, the performance was comparable during the hot season.

2. Both $\mathrm{CO}_{2}$ bio-fixation and wastewater purification were significantly impaired during the hot season, the bio-fixation rate decreasing by $30-60 \%$ and the wastewater contaminates decreased in a similar amount.

3. Optimum performance was observed at a $C_{c, g}$ value of $10 \% \mathrm{v} / \mathrm{v}$ for all parameters other than COD and TP removal during the mild season for the MIMA culture, where the optimum was $15 \%$.

4. The performance of the MIMA culture was more sensitive to both $C_{c, g}$ and season, all performance parameters showing a steep decline both from Period \#4 (the mild season) to Periods \#2-3 (the hot season) and from the optimum $C_{c, g}$ value (10 or 15\%) to higher values.

5. Based solely on a consideration of operating energy, there a significant net energy benefit (of up to $4.4 \mathrm{kWh} \cdot \mathrm{m}^{-3}$ for the mixed culture) from cooling the biomass during the hot season to sustain the highest productivities, when reasonable assumptions are made concerning evaporative cooling and losses.

There is significant benefit from employing the indigenous mixed culture and optimizing both the feed gas concentration and the culture temperature. Maintaining culture temperature incurs energy demand for cooling during the hot season, which a rudimentary energy balance suggests it is more than compensated for the embedded energy of the algal biomass generated. 
However, a full techno-economic analysis (TEA) is needed to comprehensively appraise the implications of these operational parameters.

\section{Recommendations and future perspective}

Several attempts have been made to develop effective carbon capture and storage technologies (CCSTs) as well as advanced wastewater treatments with performance and economic feasibility barriers affect their practical applications. However, the dual action of microalgae for both biofixation of $\mathrm{CO}_{2}$ from flue gases and removal of nutrients from wastewater offer a substantial economic alternative. In this scenario, $\mathrm{CO}_{2}$ and wastewater contaminates are reduced from ecosystem producing algae strains that can be converted afterward to biofuels and high-valueadded products. Microalgae, naturally grown in water bodies, have the advantage of adding value to the treated wastewater and not competing with freshwater resources

Upon completion of this study, the following is recommended;

1- Large scale pilot plants testing is pivotal to generate the required data using various algae strains;

2- Assess the economic feasibility and Life Cycle Analysis of the system in large scale operations;

3- Given the discrepancy between the bench and pilot scale testing results for microalgae growth rates, biomass productivity, and $\mathrm{CO}_{2}$ bio-fixation rate; it is highly recommended that extrapolations bench-scale tests are avoided. Proper scale-up studies should be considered at a near life pilot scale systems using data generated at the laboratory level;

4- Apply full-scale operation on systems that incorporate wastewater treatment and reduce GHG emissions from industrial flue gases while producing biofuel;

5- Develop an effective biomass harvesting technologies;

6- Focus and provide more in-depth analysis of energy value and economic viability of the biofuel and products generated from microalgae when using $\mathrm{CO}_{2}$-wastewater as a feed to the MTC process.

\section{ACKNOWLEDGMENTS}

This work was made possible by the support of a National Priorities Research Program (NPRP) grant from the Qatar National Research Fund (QNRF), grant reference number NPRP 61436-2-581. The statements made herein are solely the responsibility of the authors.

\section{References}

Abou-Shanab RA, Ji M-K, Kim H-C, Paeng K-J, Jeon B-H. Microalgal species growing on piggery wastewater as a valuable candidate for nutrient removal and biodiesel production. Journal of environmental management 2013; 115: 257-264.

Abreu AP, Fernandes B, Vicente AA, Teixeira J, Dragone G. Mixotrophic cultivation of Chlorella vulgaris using industrial dairy waste as organic carbon source. Bioresource technology 2012; 118: 61-66.

Adamczyk M, Lasek J, Skawińska A. CO2 Biofixation and Growth Kinetics of Chlorella vulgaris and Nannochloropsis gaditana. Applied biochemistry and biotechnology 2016; 179: $1248-1261$.

Al Ketife AM, Judd S, Znad H. Optimization of cultivation conditions for combined nutrient removal and $\mathrm{CO} 2$ fixation in a batch photobioreactor. Journal of Chemical Technology \& Biotechnology 2017; 92: 1085-1093. 
Al Ketife AMD, Judd S, Znad H. A mathematical model for carbon fixation and nutrient removal by an algal photobioreactor. Chemical Engineering Science 2016; 153: 354-362.

Allagui A, Sarfraz S, Ntais S, Al momani F, Baranova EA. Electrochemical behavior of ammonia on Ni98Pd2 nano-structured catalyst. International Journal of Hydrogen Energy 2014; 39: 41-48.

Almomani F, Judd S, Shurai M, Bhosale R, Kumar A, Khreisheh M. Potential use of mixed indigenous microalgae for carbon dioxide bio-fixation and advanced wastewater treatment. Environmental Division 2017 - Core Programming Area at the 2017 AIChE Spring Meeting and 13th Global Congress on Process Safety. AIChE, San Antonio; United States, 2017.

Almomani FA, Delatolla R, Örmeci B. Field study of moving bed biofilm reactor technology for post-treatment of wastewater lagoon effluent at $1{ }^{\circ} \mathrm{C}$. Environmental Technology 2014; 35: $1596-1604$.

AlMomani FA, Örmeci B. Performance Of Chlorella Vulgaris, Neochloris Oleoabundans, and mixed indigenous microalgae for treatment of primary effluent, secondary effluent and centrate. Ecological Engineering 2016; 95: 280-289.

Almomani FA, Örmeci B. Monitoring and measurement of microalgae using the first derivative of absorbance and comparison with chlorophyll extraction method. Environmental Monitoring and Assessment 2018; 190: 90.

Anis A, Nicolas B, Hussain A, Fares Am, A. BE. Cathodic Contact Glow Discharge Electrolysis for the Degradation of Liquid Ammonia Solutions. Plasma Processes and Polymers 2015; 12: $25-31$.

Arbib Z, de Godos I, Ruiz J, Perales JA. Optimization of pilot high rate algal ponds for simultaneous nutrient removal and lipids production. Science of The Total Environment 2017; 589: 66-72.

Bai X, Acharya K. Algae-mediated removal of selected pharmaceutical and personal care products (PPCPs) from Lake Mead water. Science of The Total Environment 2017; 581582: 734-740.

Beal CM, Hebner RE, Webber ME, Ruoff RS, Seibert AF. The energy return on investment for algal biocrude: results for a research production facility. BioEnergy Research 2012; 5: 341-362.

Blaas H, Kroeze C. Possible future effects of large-scale algae cultivation for biofuels on coastal eutrophication in Europe. Science of The Total Environment 2014; 496: 45-53.

Bouterfas R, Belkoura M, Dauta A. Light and temperature effects on the growth rate of three freshwater [2pt] algae isolated from a eutrophic lake. Hydrobiologia 2002; 489: 207-217.

Brock TD, Brock ML. Effect of light intensity on photosynthesis by thermal algae adapted to natural and reduced sunlight. Limnology and Oceanography 1969; 14: 334-341.

Cabello J, Morales M, Revah S. Carbon dioxide consumption of the microalga Scenedesmus obtusiusculus under transient inlet $\mathrm{CO} 2$ concentration variations. Science of The Total Environment 2017; 584-585: 1310-1316.

de Godos I, Mendoza JL, Acién FG, Molina E, Banks CJ, Heaven S, et al. Evaluation of carbon dioxide mass transfer in raceway reactors for microalgae culture using flue gases. Bioresource Technology 2014; 153: 307-314.

Do MH, Ngo HH, Guo WS, Liu Y, Chang SW, Nguyen DD, et al. Challenges in the application of microbial fuel cells to wastewater treatment and energy production: A mini review. Science of The Total Environment 2018; 639: 910-920. 
Farrell C, Hassard F, Jefferson B, Leziart T, Nocker A, Jarvis P. Turbidity composition and the relationship with microbial attachment and UV inactivation efficacy. Science of The Total Environment 2018; 624: 638-647.

Fernández JS, González-López C, Fernández FA, Sevilla JF, Grima EM. Utilization of Anabaena sp. in CO 2 removal processes. Applied microbiology and biotechnology 2012; 94: 613624.

Gao F, Peng Y-Y, Li C, Yang G-J, Deng Y-B, Xue B, et al. Simultaneous nutrient removal and biomass/lipid production by Chlorella sp. in seafood processing wastewater. Science of The Total Environment 2018; 640-641: 943-953.

Gonçalves AL, Rodrigues CM, Pires JC, Simões M. The effect of increasing CO2 concentrations on its capture, biomass production and wastewater bioremediation by microalgae and cyanobacteria. Algal research 2016; 14: 127-136.

Hammond GP, Spargo J. The prospects for coal-fired power plants with carbon capture and storage: A UK perspective. Energy Conversion and Management 2014; 86: 476-489.

Hatnagar A, M. , Bhatnagar S, Chinnasamy K, B D. Chlorella minutissima-a promising fuel alga for cultivation in municipal wastewaters. Applied Biochemistry and Biotechnology 2010; 161: 523-536.

Ho S-H, Liao J-F, Chen C-Y, Chang J-S. Combining light strategies with recycled medium to enhance the economic feasibility of phycocyanin production with Spirulina platensis. Bioresource Technology 2018; 247: 669-675.

Judd S, van den Broeke LJ, Shurair M, Kuti Y, Znad H. Algal remediation of CO2 and nutrient discharges: a review. Water research 2015; 87: 356-366.

Judd SJ, Al Momani FAO, Znad H, Al Ketife AMD. The cost benefit of algal technology for combined $\mathrm{CO} 2$ mitigation and nutrient abatement. Renewable and Sustainable Energy Reviews 2017; 71: 379-387.

Kang M, Tian Y, Peng S, Wang M. Effect of dissolved oxygen and nutrient levels on heavy metal contents and fractions in river surface sediments. Science of The Total Environment 2019; 648: 861-870.

Kasprzyk M, Gajewska M. Phosphorus removal by application of natural and semi-natural materials for possible recovery according to assumptions of circular economy and closed circuit of P. Science of The Total Environment 2019; 650: 249-256.

Kassim MA, Meng TK. Carbon dioxide (CO2) biofixation by microalgae and its potential for biorefinery and biofuel production. Science of The Total Environment 2017; 584-585: 1121-1129.

Kumari A, Kumar A, Pathak AK, Guria C. Carbon dioxide assisted Spirulina platensis cultivation using NPK-10:26:26 complex fertilizer in sintered disk chromatographic glass bubble column. Journal of CO2 Utilization 2014; 8: 49-59.

Lalucat J, Imperial J, Parés R. Utilization of light for the assimilation of organic matter in Chlorella sp. VJ79. Biotechnology and Bioengineering 1984; 26: 677-681.

Lam MK, Lee KT. Effect of carbon source towards the growth of Chlorella vulgaris for $\mathrm{CO} 2$ bio-mitigation and biodiesel production. International Journal of Greenhouse Gas Control 2013; 14: 169-176.

Lam MK, Lee KT. Cultivation of Chlorella vulgaris in a pilot-scale sequential-baffled column photobioreactor for biomass and biodiesel production. Energy conversion and management 2014; 88: 399-410. 
Li C, Yang H, Xia X, Li Y, Chen L, Zhang M, et al. High efficient treatment of citric acid effluent by Chlorella vulgaris and potential biomass utilization. Bioresource Technology 2013; 127: 248-255.

Li J, Xu NS, Su WW. Online estimation of stirred-tank microalgal photobioreactor cultures based on dissolved oxygen measurement. Biochemical Engineering Journal 2003; 14: 5165.

Liang M. Cultivation of green algae Chlorella sp. in different wastewaters from municipal wastewater treatment plant. Appl. Biochem. Biotechnol. 2009; 160: 1744-1751.

Liu H, Chen H, Wang S, Liu Q, Li S, Song X, et al. Optimizing light distribution and controlling biomass concentration by continuously pre-harvesting Spirulina platensis for improving the microalgae production. Bioresource technology 2018; 252: 14-19.

Marbelia L, Bilad MR, Passaris I, Discart V, Vandamme D, Beuckels A, et al. Membrane photobioreactors for integrated microalgae cultivation and nutrient remediation of membrane bioreactors effluent. Bioresource technology 2014; 163: 228-235.

Martin C, De la Noüe J, Picard G. Intensive cultivation of freshwater microalgae on aerated pig manure. Biomass 1985; 7: 245-259.

Moheimani NR, Borowitzka MA. Limits to productivity of the alga Pleurochrysis carterae (Haptophyta) grown in outdoor raceway ponds. Biotechnology and Bioengineering 2007; 96: 27-36.

Nourmohammadi D, Esmaeeli M-B, Akbarian H, Ghasemian M. Nitrogen removal in a full-scale domestic wastewater treatment plant with activated sludge and trickling filter. Journal of environmental and public health 2013; 2013.

Ota M, Takenaka M, Sato Y, Jr RLS, Inomata H. Effects of light intensity and temperature on photoautotrophic growth of a green microalga, Chlorococcum littorale. Biotechnology Reports 2015; 7: 24-29.

Rafferty KD, Culver G. Heat exchangers. Geothermal Direct Use Engineering and Design Guidebook 1998: 261-77.

Razzak SA, Hossain MM, Lucky RA, Bassi AS, de Lasa H. Integrated CO2 capture, wastewater treatment and biofuel production by microalgae culturing-A review. Renewable and sustainable energy reviews 2013; 27: 622-653.

Richmond A. Physiological principles and modes of cultivation in mass production of photoautotrophic microalgae. Chemicals from Microalgae 1999: 353-86.

Ruiz-Martinez A, Garcia NM, Romero I, Seco A, Ferrer J. Microalgae cultivation in wastewater: nutrient removal from anaerobic membrane bioreactor effluent. Bioresource Technology 2012; 126: 247-253.

Schneider SC, Kahlert M, Kelly MG. Interactions between $\mathrm{pH}$ and nutrients on benthic algae in streams and consequences for ecological status assessment and species richness patterns. Science of The Total Environment 2013; 444: 73-84.

Silva HJ, Pirt SJ. Carbon dioxide inhibition of photosynthetic growth of Chlorella. Microbiology 1984; 130: 2833-2838.

Singh NK, Dhar DW. Microalgae as second generation biofuel. A review. Agronomy for Sustainable Development 2011; 31: 605-629.

Singh S, Singh P. Effect of temperature and light on the growth of algae species: a review. Renewable and Sustainable Energy Reviews 2015; 50: 431-444. 
Singh SK, Rahman A, Dixit K, Nath A, Sundaram S. Evaluation of promising algal strains for sustainable exploitation coupled with CO2 fixation. Environmental Technology 2016; 37 : 613-622.

Stoever HJ. Applied heat transmission. 1941.

Sung K-D, Lee J-S, Shin C-S, Park S-C, Choi M-J. CO2 fixation by Chlorella sp. KR-1 and its cultural characteristics. Bioresource technology 1999; 68: 269-273.

Sutherland DL, Howard-Williams C, Turnbull MH, Broady PA, Craggs RJ. Seasonal variation in light utilisation, biomass production and nutrient removal by wastewater microalgae in a full-scale high-rate algal pond. Journal of applied phycology 2014; 26: 1317-1329.

Sutherland DL, Howard-Williams C, Turnbull MH, Broady PA, Craggs RJ. Frequency of CO2 supply affects wastewater microalgal photosynthesis, productivity and nutrient removal efficiency in mesocosms: implications for full-scale high rate algal ponds. Journal of applied phycology 2015; 27: 1901-1911.

Sydney E, Sturm W, De Carvalho J, Thomaz-Soccol V, Larroche C, Pandey A, et al. Potential carbon dioxide fixation by industrially important microalgae. Vol 101, 2010.

Tang D, Han W, Li P, Miao X, Zhong J. CO2 biofixation and fatty acid composition of Scenedesmus obliquus and Chlorella pyrenoidosa in response to different $\mathrm{CO} 2$ levels. Bioresource technology 2011; 102: 3071-3076.

Teoh M-L, Chu W-L, Marchant H, Phang S-M. Influence of culture temperature on the growth, biochemical composition and fatty acid profiles of six Antarctic microalgae. Journal of Applied Phycology 2004; 16: 421-430.

Toledo-Cervantes A, Morales T, González Á, Muñoz R, Lebrero R. Long-term photosynthetic $\mathrm{CO} 2$ removal from biogas and flue-gas: Exploring the potential of closed photobioreactors for high-value biomass production. Science of The Total Environment 2018; 640-641: 1272-1278.

Wang L, M. , Min YL, P. Chen, Y. Chen, Y. Y. Liu W, Ruan. R. Cultivation of Green Algae Chlorella sp. in Different Wastewaters from Municipal Wastewater Treatment Plant. . Applied Biochemistry and Biotechnology 2009; 162: 1174-1186.

Wang Y, Zhao L, Otto A, Robinius M, Stolten D. A Review of Post-combustion CO2 Capture Technologies from Coal-fired Power Plants. Energy Procedia 2017; 114: 650-665.

Wang $\mathrm{Z}$, Wen $\mathrm{X}, \mathrm{Xu} \mathrm{Y}$, Ding Y, Geng Y, Li Y. Maximizing CO2 biofixation and lipid productivity of oleaginous microalga Graesiella sp. WBG-1 via CO2-regulated $\mathrm{pH}$ in indoor and outdoor open reactors. Science of The Total Environment 2018; 619-620: 827-833.

Wilberforce T, Baroutaji A, Soudan B, Al-Alami AH, Olabi AG. Outlook of carbon capture technology and challenges. Science of The Total Environment 2019; 657: 56-72.

Xue S, Su Z, Cong W. Growth of Spirulina platensis enhanced under intermittent illumination. Journal of Biotechnology 2011; 151: 271-277.

Yuan X, Kumar A, Sahu AK, Ergas SJ. Impact of ammonia concentration on Spirulina platensis growth in an airlift photobioreactor. Bioresource technology 2011; 102: 3234-3239.

Zhang J, Nwani O, Tan Y, Agar DW. Carbon dioxide absorption into biphasic amine solvent with solvent loss reduction. Chemical Engineering Research and Design 2011; 89: 11901196.

Zhimiao Z, Xinshan S, Yanping X, Yufeng Z, Zhijie G, Fanda L, et al. Influences of seasons, $\mathrm{N} / \mathrm{P}$ ratios and chemical compounds on phosphorus removal performance in algal pond 
combined with constructed wetlands. Science of The Total Environment 2016; 573: 906914.

Zhou W, Li Y, Gao Y, Zhao H. Nutrients removal and recovery from saline wastewater by Spirulina platensis. Bioresource Technology 2017a; 245: 10-17.

Zhou W, Wang J, Chen P, Ji C, Kang Q, Lu B, et al. Bio-mitigation of carbon dioxide using microalgal systems: Advances and perspectives. Renewable and Sustainable Energy Reviews 2017b; 76: 1163-1175.

Ziegler P, Sree K, Appenroth K-J. Duckweeds for water remediation and toxicity testing. Toxicological \& Environmental Chemistry 2016; 98: 1127-1154.

Znad H, Al Ketife AM, Judd S, AlMomani F, Vuthaluru HB. Bioremediation and nutrient removal from wastewater by Chlorella vulgaris. Ecological Engineering 2018a; 110: 1-7.

Znad H, Al Ketife AMD, Judd S. Enhancement of CO2 biofixation and lipid production by Chlorella vulgaris using coloured polypropylene film. Environmental Technology 2018b: $1-7$. 


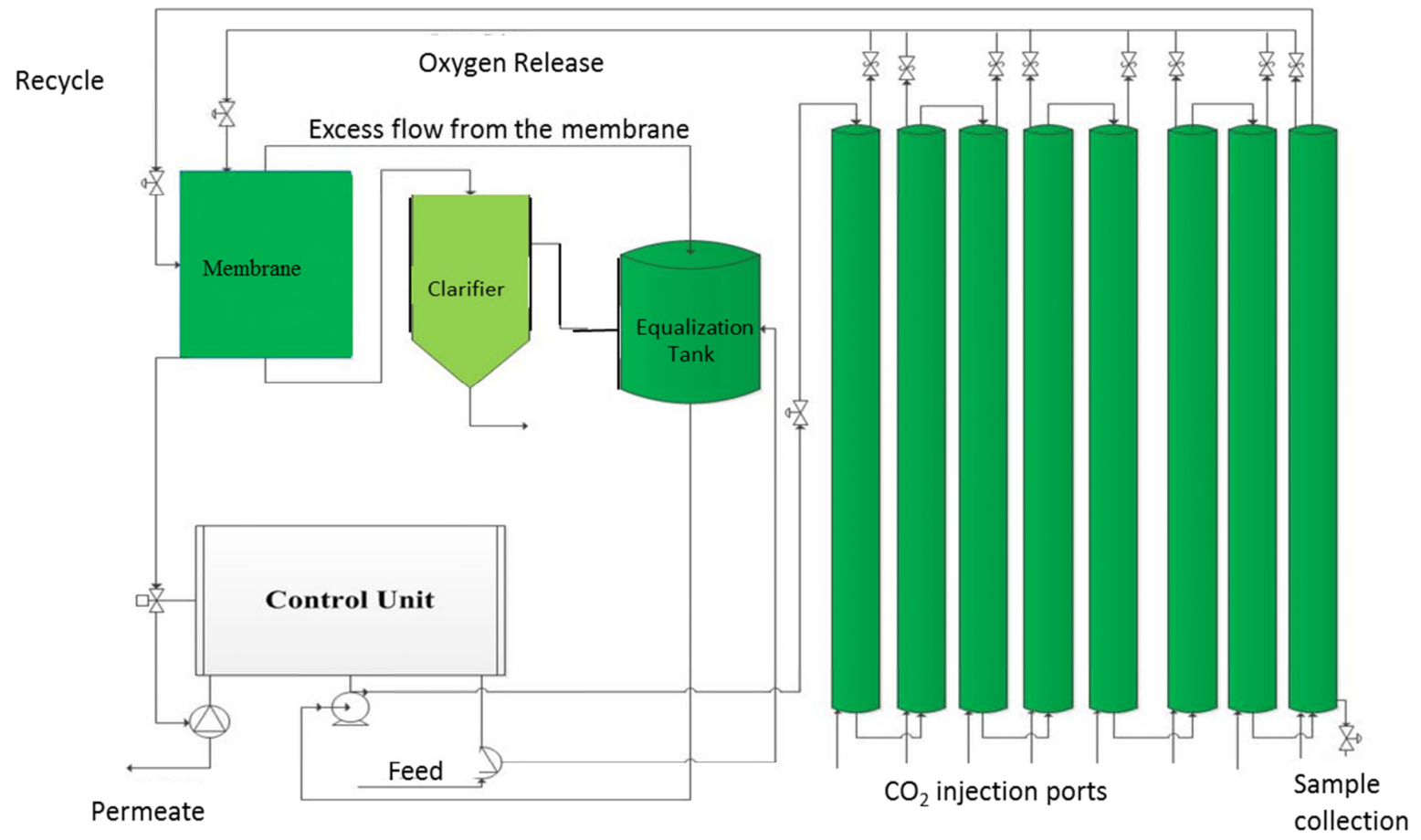

Figure 1: $\quad$ PBR pilot plant, schematic 

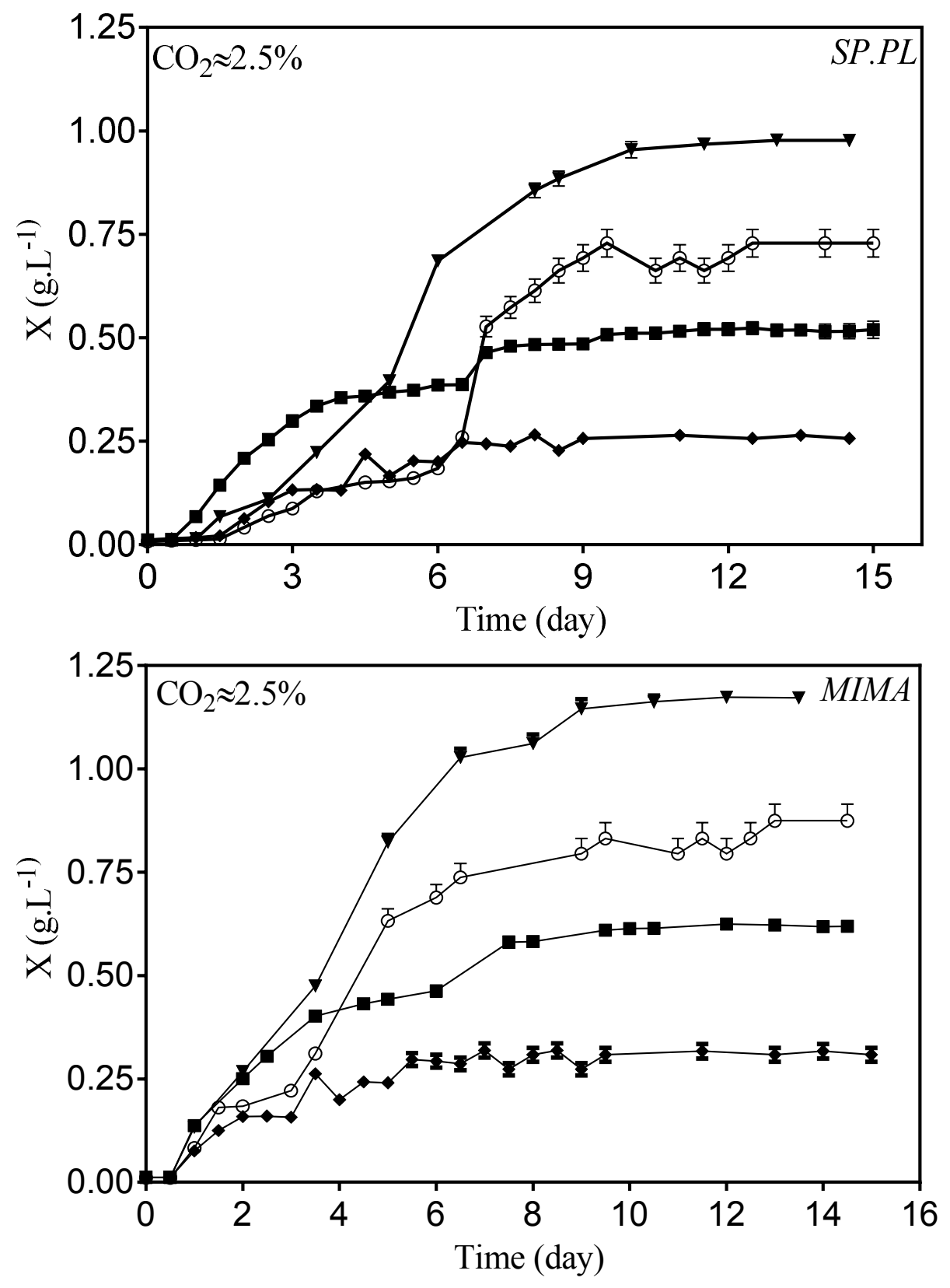

$\rightarrow$ Period \# $1 \rightarrow$ Period \# $2 \rightarrow$ Period \# $3 \rightarrow$ Period \# 4

Figure 2: $\quad$ Biomass concentrations of SP.PL and MIMA biomass as a function of cultivation time at different cultivation periods and a $\mathrm{CO}_{2}$ dose of 2.5\%. Periods: (1) Jan-Mar, (2) Apr-Jun, (3) JulSep and (4) Oct-Dec. 


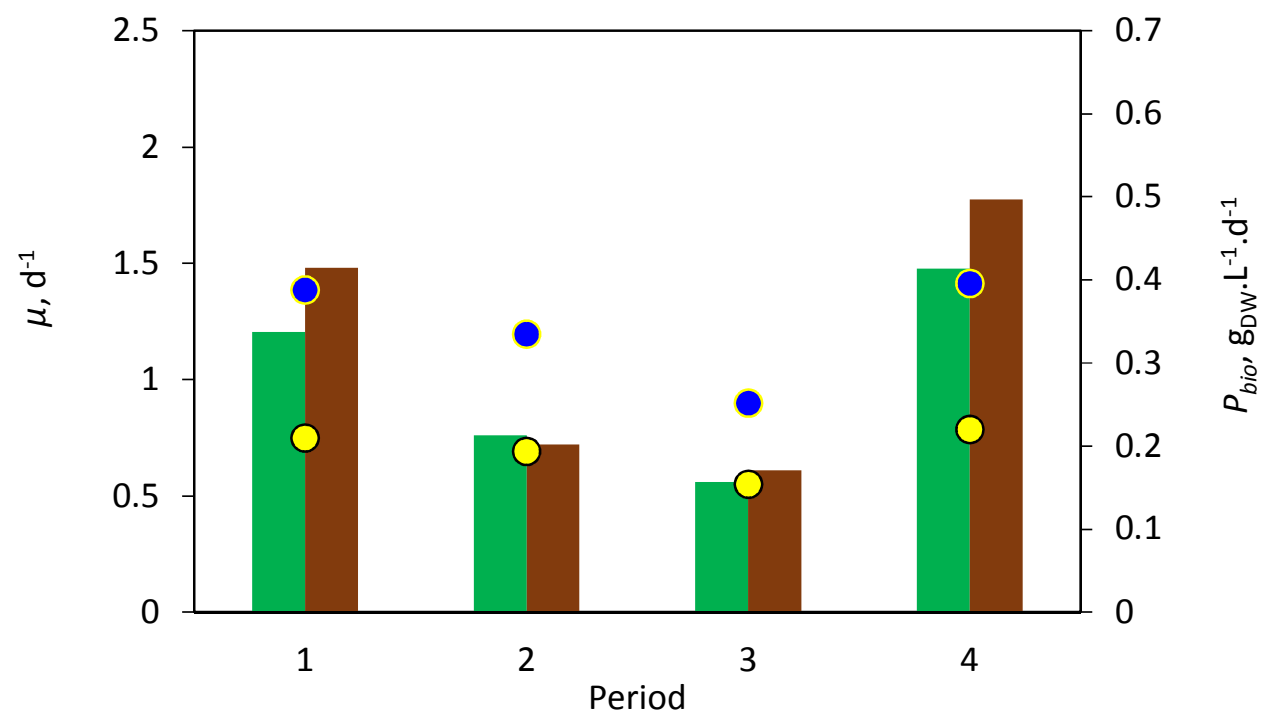

(a)

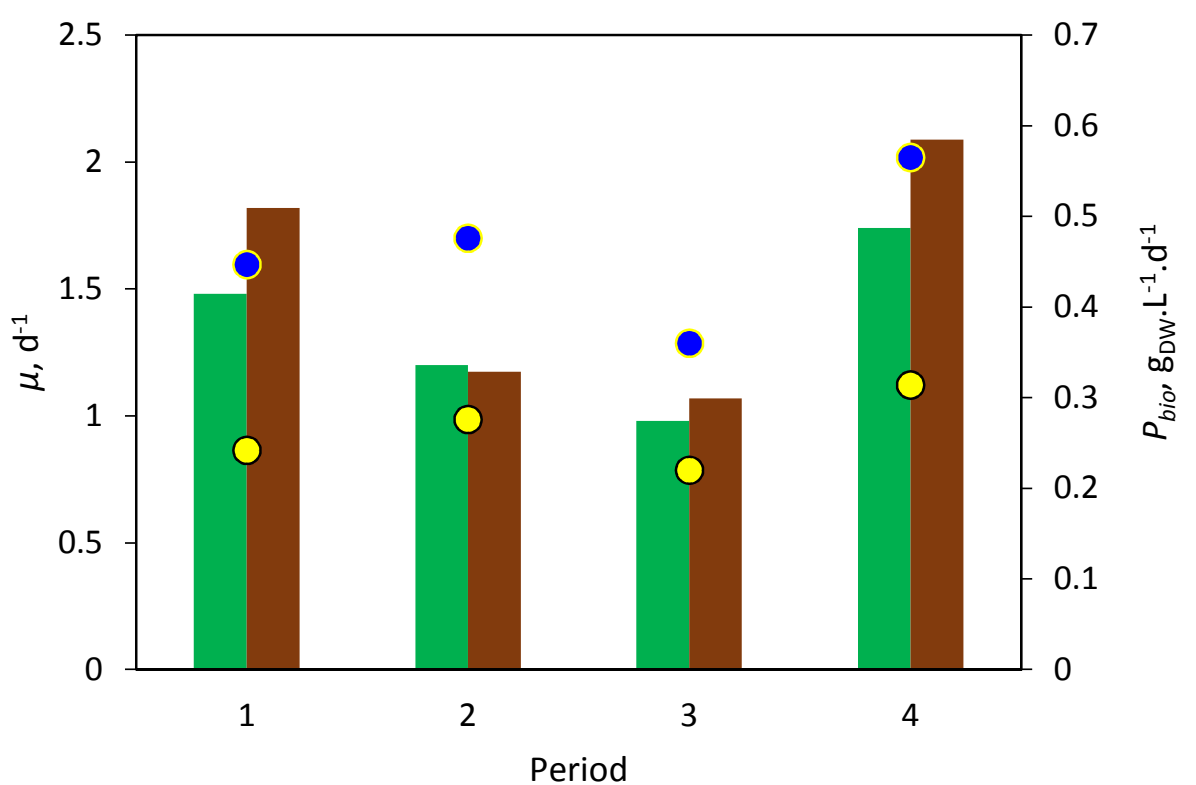

(b) 


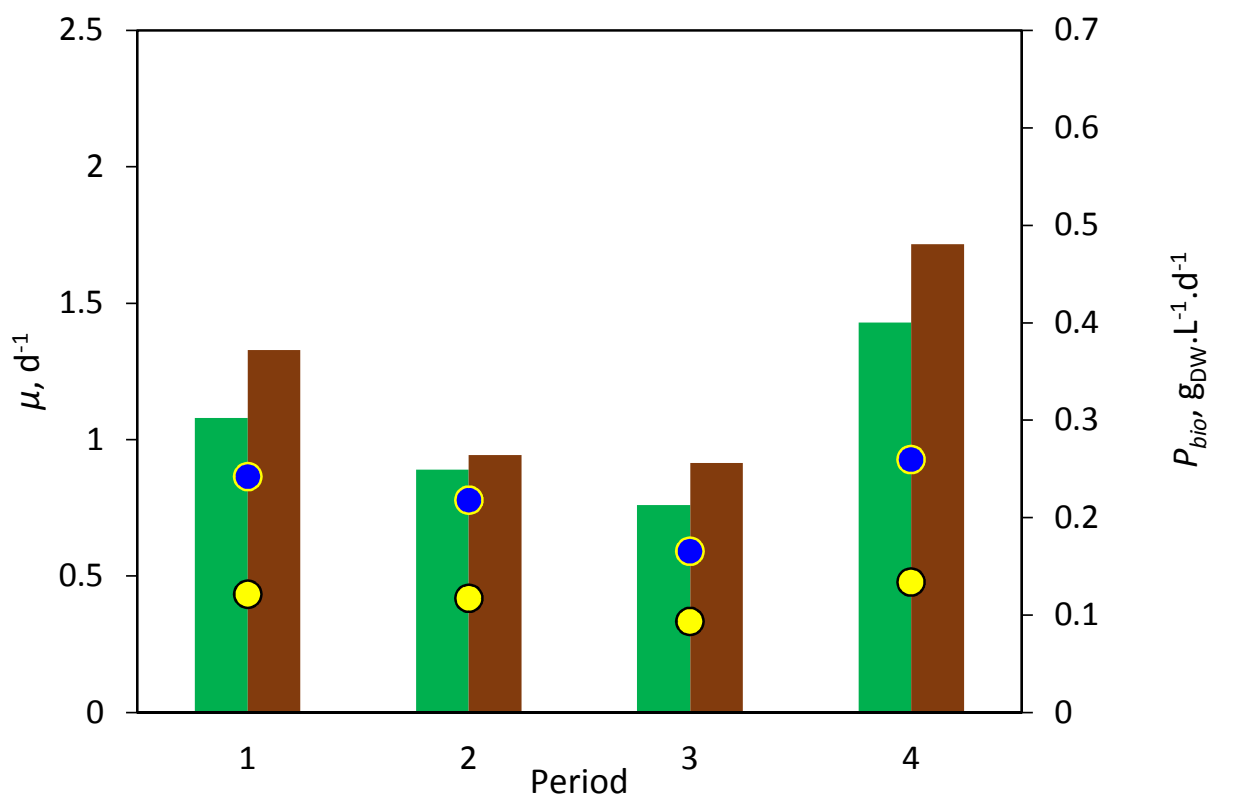

(c)

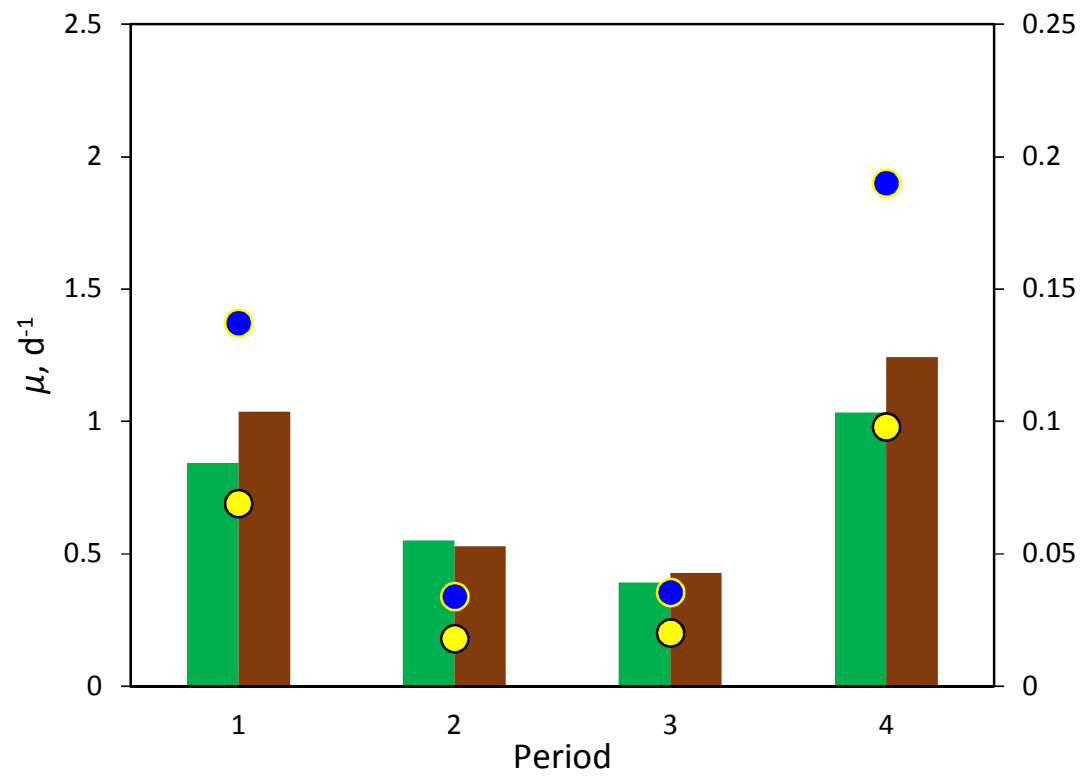

-

(d)

$\square$, SP.PL $\square \mu$, MIMA OPbio, SP.PL $\bullet$ Pbio, MIMA

Figure 3: $\quad$ Mean $\mu$ and $P_{b i o}$ values for the two species at different periods at $C_{c, g}$ of (a) $2.5 \%$, (b) $10 \%$, (c) $15 \%$ and (d) $20 \%$ v/v. Periods: (1) Jan-Mar, (2) Apr-Jun, (3) Jul-Sep and (4) Oct-Dec 


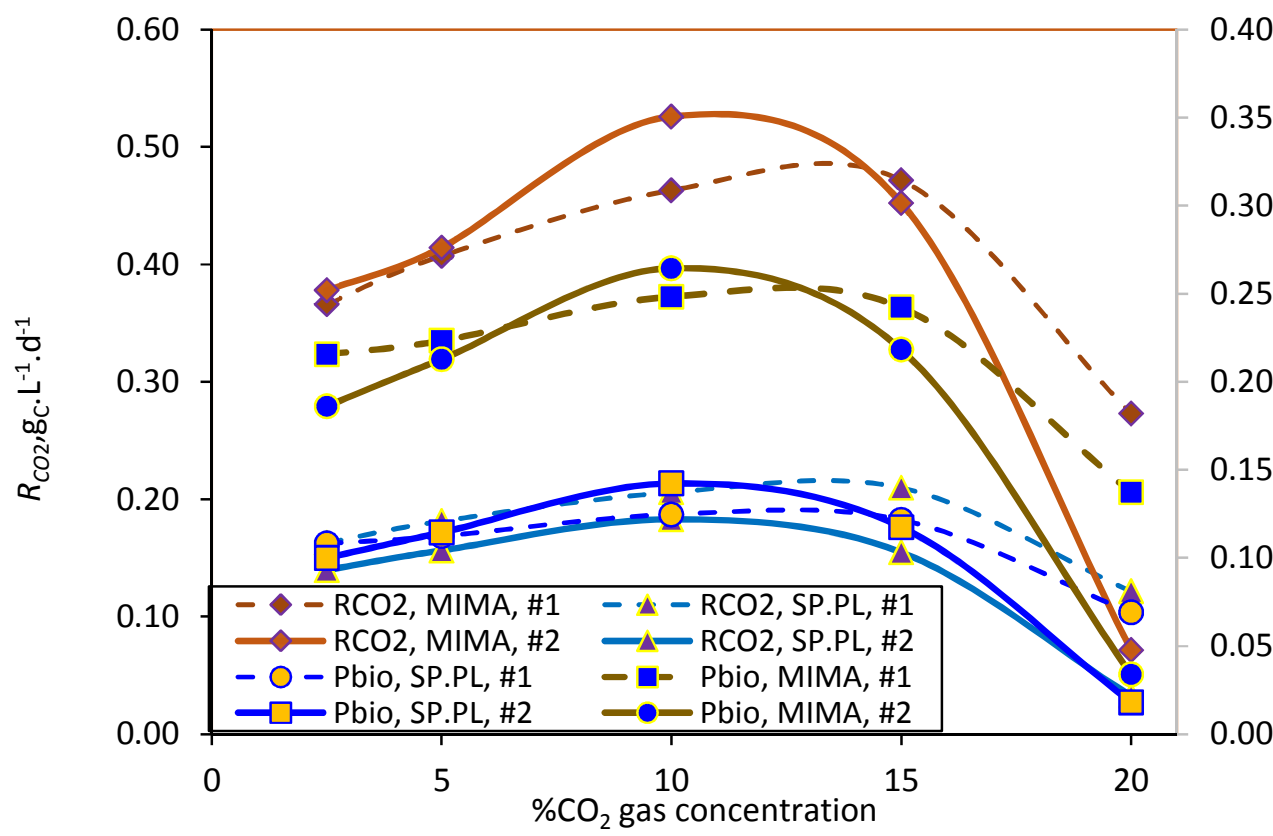

(b)

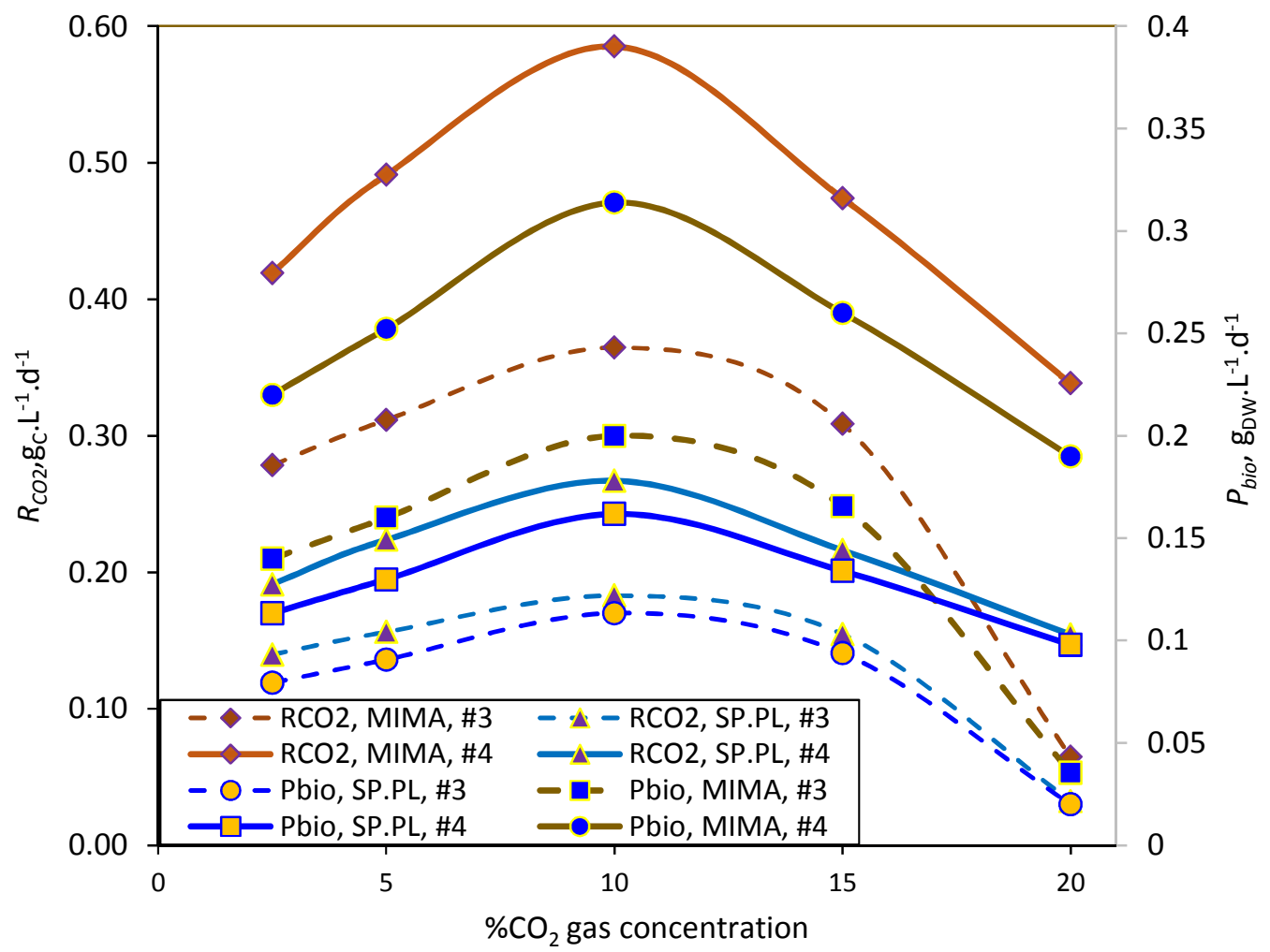

Figure 4: $\quad$ Carbon fixation rate $\left(R_{\mathrm{CO}_{2}}\right)$ and productivity $\left(P_{\text {bio }}\right)$ as a function of feed gas $\mathrm{CO}_{2}$ concentration for the two algal strains (SP.PL and MIMA) for (a) Periods \#1 and \#2, and (b) Periods \#3 and \#4 


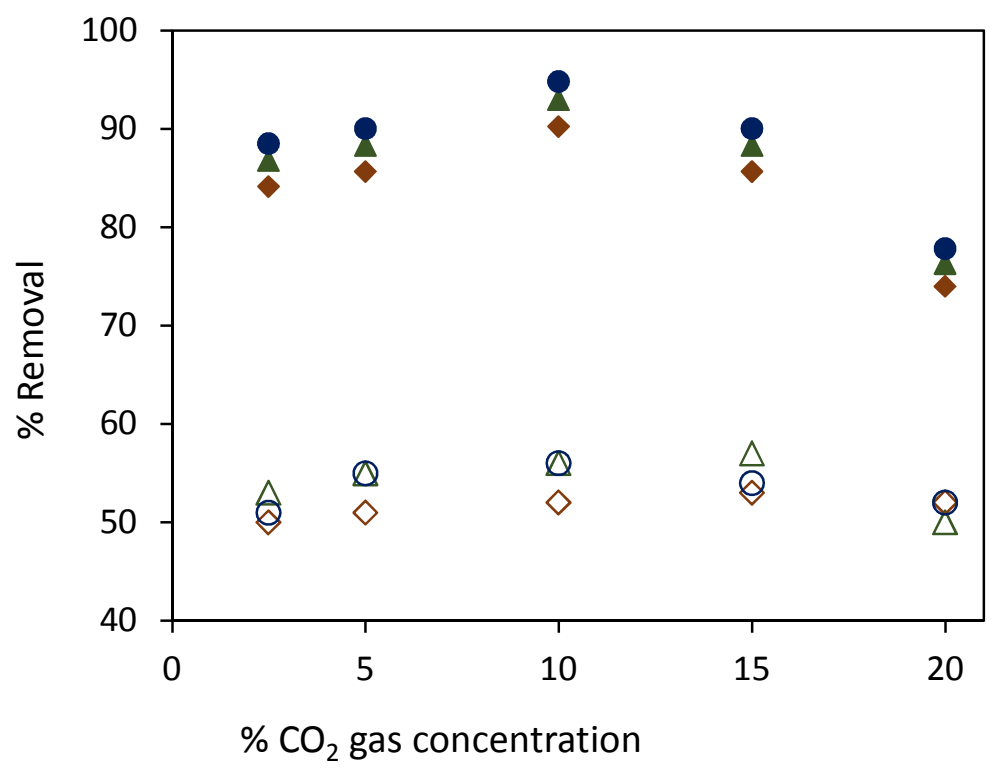

(a)

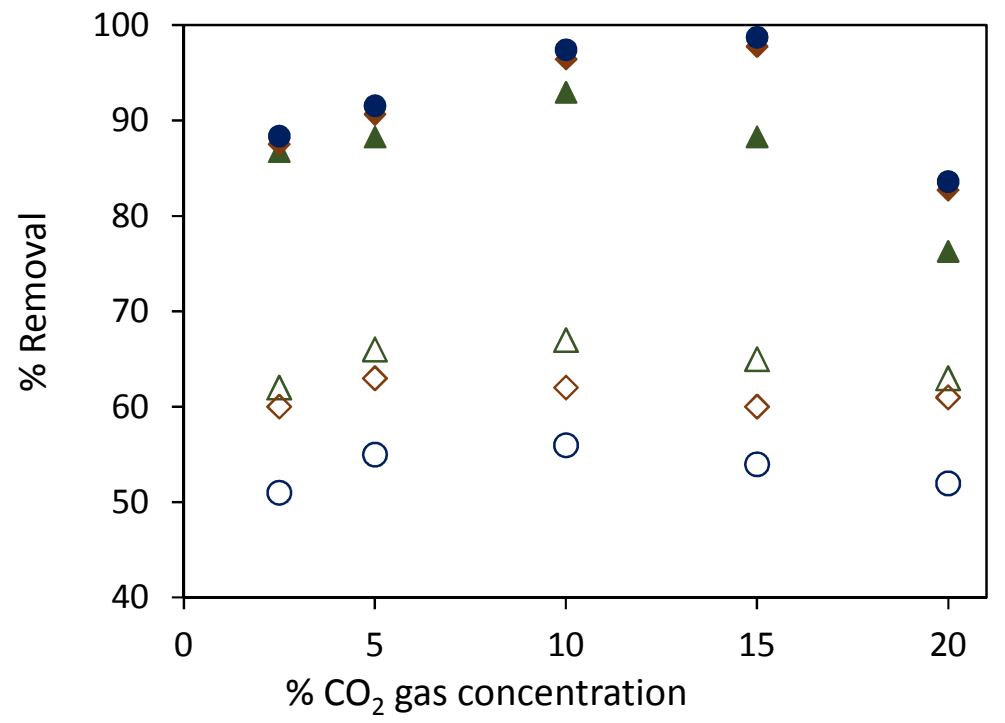

(b)

$$
\begin{array}{lll}
\triangle \mathrm{TIN}, \# 3 & \diamond \mathrm{TP}, \# 3 & \circ \mathrm{COD}, \# 3 \\
\triangle \mathrm{TIN}, \# 4 & \bullet \mathrm{TP}, \# 4 & \bullet \mathrm{COD}, \# 4
\end{array}
$$

Figure 5: $\quad$ Nutrient and carbon removal and $\mathrm{CO}_{2}$ biofixation $\left(\mathrm{R}_{\mathrm{CO} 2}\right)$ trends with feed gas $\mathrm{CO}_{2}$ concentration for (a) SP.PL, and (b) MIMA for Periods \#3 and \#4. 
Table 1: Characteristics of the secondary effluent used in the experiments

\begin{tabular}{l|lll}
\hline Parameter & Lower limit & Upper limit & Average \\
\hline $\mathrm{COD}_{\mathrm{s}}\left(\mathrm{mg} . \mathrm{L}^{-1}\right)$ & $50.0 \pm 1.5$ & $59.0 \pm 0.5$ & $52.0 \pm 0.5$ \\
$\mathrm{NH}_{4}^{+}\left(\mathrm{mg}-\mathrm{N} / \mathrm{L}^{-1}\right)$ & $40.0 \pm 0.2$ & $44.0 \pm 0.2$ & $42.0 \pm 1.5$ \\
$\mathrm{NO}_{2}^{-}\left(\mathrm{mg}-\mathrm{N} / \mathrm{L}^{-1}\right)$ & $0.77 \pm 0.06$ & $0.89 \pm 0.06$ & $0.81 \pm 0.06$ \\
$\mathrm{NO}_{3}^{-}\left(\mathrm{mg}-\mathrm{N} / \mathrm{L}^{-1}\right)$ & $9.0 \pm 0.1$ & $18.0 \pm 0.1$ & $10.5 \pm \pm 0.1$ \\
Total Phosphorus $\left(\mathrm{mg} / \mathrm{L}^{-1}\right)$ & $8.0 \pm 0.2$ & $14.0 \pm 0.2$ & $9.3 \pm 0.3$ \\
$\mathrm{~N}: \mathrm{P}$ ratio & $5.95: 1$ & $4.50: 1$ & $5.73: 1$ \\
$\mathrm{C}: \mathrm{N}: \mathrm{P}$ ratio & $6.25: 5.95: 1$ & $4.2: 4.50: 1$ & $5.6: 5.73: 1$ \\
$\mathrm{pH}$ & 7.2 & 7.53 & 7.1 \\
\hline
\end{tabular}


Table 2: Key operating parameter values of the PBR

\begin{tabular}{|c|c|c|c|c|c|c|c|c|c|c|c|c|c|c|}
\hline Period & Months & $\begin{array}{c}T_{A, \text { low }},{ }^{\circ} \mathrm{C} \\
(\text { Std.Dev })^{90}\end{array}$ & $\begin{array}{c}T_{\text {A,ave, }}{ }^{\circ} C \\
(\text { Std.Dev })^{90^{*}}\end{array}$ & $\begin{array}{c}T_{A, \text { high }}{ }^{\circ} \mathrm{C} \\
(\text { Std.Dev })^{90}\end{array}$ & $\begin{array}{c}T_{B, \text { Low }} \\
\left.{ }^{\circ} \text { C(Std.Dev }\right)^{90}\end{array}$ & $\begin{array}{c}T_{B, \text { ave }} \\
{ }^{\circ} \mathrm{C}(\mathrm{Std} . \mathrm{Dev})^{90}\end{array}$ & $\begin{array}{c}T_{B, \text { high }} \\
{ }^{\circ} \mathrm{C}(\mathrm{Std} . \mathrm{Dev})^{90}\end{array}$ & $\begin{array}{c}T_{\text {low }} \\
h(\text { Std.Dev })^{90}\end{array}$ & $\begin{array}{c}\tau_{\text {ave }} \\
\boldsymbol{h}\end{array}$ & $\begin{array}{c}T_{\text {high, }} \\
h(\text { Std.Dev })^{90}\end{array}$ & $\begin{array}{c}\boldsymbol{I}_{\text {low }} \\
\underset{{ }^{2} \boldsymbol{s}^{-1}}{-1} \\
\end{array}$ & $I_{\text {ave }} \underset{{ }^{2} s^{-1}}{\mu E} m^{-}$ & $\begin{array}{c}I_{h i g h} \\
\mu E m^{-} \\
{ }_{2}{ }^{-1}\end{array}$ & $\begin{array}{c}I_{\text {ave }}^{\prime}, E \\
m^{-2}\end{array}$ \\
\hline 1 & $\begin{array}{l}\text { Jan- } \\
\text { Mar }\end{array}$ & $\begin{array}{l}18.1 \\
(1.7)\end{array}$ & $\begin{array}{l}21.6 \\
(2.5)\end{array}$ & $\begin{array}{l}24.3 \\
(2.6)\end{array}$ & $\begin{array}{l}16.0 \\
(1.9)\end{array}$ & $\begin{array}{l}18.3 \\
(1.3)\end{array}$ & $\begin{array}{l}20.4 \\
(2.2)\end{array}$ & $\begin{array}{l}10.5 \\
(0.8)^{10}\end{array}$ & $\begin{array}{l}11.2 \\
(0.7)\end{array}$ & $\begin{array}{l}11.8 \\
(0.8)\end{array}$ & $105 \pm 6$ & $115 \pm 10$ & $135 \pm 6$ & 4.64 \\
\hline 2 & $\begin{array}{l}\text { Apr- } \\
\text { Jun }\end{array}$ & $28.7(3.2)$ & $\begin{array}{l}30.0 \\
1.6)\end{array}$ & $\begin{array}{l}36.0 \\
(3.6)\end{array}$ & $\begin{array}{l}26.5 \\
(2.1)\end{array}$ & $\begin{array}{l}29.0 \\
(1.1)\end{array}$ & $\begin{array}{l}35.2 \\
(2.4)\end{array}$ & $\begin{array}{r}12.9 \\
(0.6) \\
\end{array}$ & $\begin{array}{l}13.0 \\
(0.4)\end{array}$ & $\begin{array}{l}13.3 \\
(0.7)\end{array}$ & $170 \pm 7$ & $189 \pm 10$ & $240 \pm 10$ & 8.85 \\
\hline 3 & Jul-Sep & $32.5(1.3)$ & $\begin{array}{l}36.2 \\
(1.3)\end{array}$ & $\begin{array}{l}41.2 \\
(0.9)\end{array}$ & $\begin{array}{l}27.8 \\
(1.2)\end{array}$ & $\begin{array}{l}32.5 \\
(1.5)\end{array}$ & $\begin{array}{l}38.0 \\
(0.8)\end{array}$ & $\begin{array}{l}12.6 \\
(0.3)\end{array}$ & $\begin{array}{l}12.9 \\
(0.5)\end{array}$ & $\begin{array}{l}13.1 \\
(0.5)\end{array}$ & $185 \pm 7$ & $210 \pm 15$ & $265 \pm 10$ & 9.75 \\
\hline 4 & $\begin{array}{l}\text { Oct- } \\
\text { Dec }\end{array}$ & $22.7(3.5)$ & $\begin{array}{l}25.0 \\
(1.8)\end{array}$ & $\begin{array}{l}31.3 \\
(4.5) \\
\end{array}$ & $\begin{array}{l}20.3 \\
(1.1) \\
\end{array}$ & $\begin{array}{l}23.0 \\
(2.0) \\
\end{array}$ & $\begin{array}{l}25.5 \\
(0.9) \\
\end{array}$ & $\begin{array}{l}10.6 \\
(0.2) \\
\end{array}$ & $\begin{array}{l}10.7 \\
(0.1) \\
\end{array}$ & $\begin{array}{l}11.0 \\
(0.2)\end{array}$ & $165 \pm 7$ & $220 \pm 10$ & $235 \pm 10$ & 8.47 \\
\hline
\end{tabular}

$T_{A, \text { ave }}$ ambient temperature; $T_{B, \text { ave }}$ bioreactor temperature; $\tau$ number of hours of daylight; $I_{\text {ave }}$ average light intensity; $I_{\text {ave }}^{\prime}$ total light received,

Std.Dev: Standard deviation, * number of data used in calculations 
Table 3: Spirulina platensis nutrient removal efficiencies (TN, TP and COD percentage removals) reported for various effluents

\begin{tabular}{|c|c|c|c|c|c|c|c|c|c|c|c|c|c|}
\hline $\begin{array}{l}\text { Mode of operation-C } \\
\text { source }\end{array}$ & $\begin{array}{l}T N_{i n} \\
m g L^{-1}\end{array}$ & 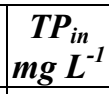 & $\begin{array}{l}\operatorname{COD}_{\text {in }} \\
\mathrm{mg} \mathrm{L}^{-1}\end{array}$ & $\begin{array}{c}T I C_{i n} \\
m g L^{-1}\end{array}$ & $\begin{array}{c}C_{c, g} \\
\% \mathrm{v} / \mathrm{v}\end{array}$ & $\begin{array}{c}I \\
\mu E m^{-2} s^{-1}\end{array}$ & $\begin{array}{l}\mathrm{T}, \\
{ }^{\circ} \mathrm{C}\end{array}$ & $\begin{array}{c}p H, \\
(-)\end{array}$ & $\begin{array}{c}\text { C/N/P or } N / P \\
\text { ratio }\end{array}$ & $\begin{array}{l}T N \\
(\%)\end{array}$ & $\begin{array}{l}T P \\
(\%)\end{array}$ & $\begin{array}{l}C O D \\
(\%)\end{array}$ & Refs \\
\hline $\begin{array}{l}\text { BioFlo- } F_{B}-\text { MBM \& } \\
\text { ZM }\end{array}$ & $\mathrm{nr}$ & $\mathrm{nr}$ & $\mathrm{nr}$ & $\mathrm{nr}$ & 15 & 68.2 & $\mathrm{nr}$ & 7.2 & $\mathrm{nr}$ & $\mathrm{nr}$ & $\mathrm{nr}$ & $\mathrm{nr}$ & $\begin{array}{l}\text { (Sydney et } \\
\text { al. 2010) }\end{array}$ \\
\hline $\begin{array}{l}\mathrm{PBR}_{\mathrm{B}}- \\
\mathrm{SWW}\end{array}$ & $\mathrm{nr}$ & $\mathrm{nr}$ & $\mathrm{nr}$ & $\mathrm{nr}$ & 6 & 84.2 & 27 & $\mathrm{nr}$ & $\mathrm{nr}$ & $\mathrm{nr}$ & $\mathrm{nr}$ & $\mathrm{nr}$ & $\begin{array}{l}\text { (Singh et al } \\
2016 \text { ) }\end{array}$ \\
\hline $\mathrm{FPBR}_{\mathrm{B}}-\mathrm{MZM}$ & 618 & 89 & $\mathrm{nr}$ & 600 & 2.5 & $400^{*}$ & $28-30$ & 9.4 & $600: 07: 01$ & $\mathrm{nr}$ & $\mathrm{nr}$ & $\mathrm{nr}$ & $\begin{array}{l}\text { (Ho et al. } \\
2018)\end{array}$ \\
\hline $\mathrm{EFPBR}_{\mathrm{B}}-\mathrm{SW}$ & 130 & 15 & 900 & $\mathrm{nr}$ & $\mathrm{nr}$ & 90 & 25 & 7.79 & $900: 7.79: 1$ & 93 & 80 & 90 & $\begin{array}{l}\text { (Zhou et al. } \\
2017 \mathrm{~b} \text { ) }\end{array}$ \\
\hline $\mathrm{CPBR} \mathrm{C}_{\mathrm{C}}-\mathrm{ZM}$ & \multirow[t]{2}{*}{444} & \multirow[t]{2}{*}{82.5} & \multirow[t]{2}{*}{$\mathrm{nr}$} & \multirow[t]{2}{*}{2400} & \multirow[t]{2}{*}{5} & \multirow[t]{2}{*}{$180 \pm 5$} & \multirow[t]{2}{*}{30} & \multirow[t]{2}{*}{$\mathrm{nr}$} & \multirow[t]{2}{*}{$2400: 05: 01$} & $\mathrm{nr}$ & 75 & $\mathrm{nr}$ & \multirow{2}{*}{$\begin{array}{l}\text { (Liu et al. } \\
2018)\end{array}$} \\
\hline $\mathrm{CPBR} \mathrm{B}_{\mathrm{B}}-\mathrm{ZM}$ & & & & & & & & & & $\mathrm{nr}$ & 67 & $\mathrm{nr}$ & \\
\hline $\mathrm{BAPBR}_{C}-\mathrm{SYWW}$ & 412 & 90 & $\mathrm{nr}$ & $\mathrm{nr}$ & 0.03 & 400 & 20 & $9-10$ & $4.5: 1$ & 49 & 81 & $\mathrm{nr}$ & $\begin{array}{l}\text { (Yuan et al. } \\
\text { 2011) }\end{array}$ \\
\hline $\mathrm{FPBR}_{\mathrm{B}}-\mathrm{ZM}$ & 407 & 115 & $\mathrm{nr}$ & 2373 & 10 & 174 & 33 & 9.2 & $2373: 04: 01$ & $\mathrm{nr}$ & $\mathrm{nr}$ & $\mathrm{nr}$ & $\begin{array}{c}\text { (Xue et al. } \\
\text { 2011) }\end{array}$ \\
\hline AA- SDCG-BC $B-C F$ & 76 & 89 & $\mathrm{nr}$ & 2340 & 100 & $\mathrm{nr}$ & $\mathrm{nr}$ & $9-10$ & $2340: 01: 01$ & 70 & 19 & $\mathrm{nr}$ & $\begin{array}{l}\text { (Kumari et } \\
\text { al. 2014) }\end{array}$ \\
\hline
\end{tabular}

BioFlo- $\mathrm{F}_{\mathrm{B}}$ BioFlo-fermenter; MBM Modified Bristol medium; ZM; Zarrouk medium; PBR $_{\mathrm{B}}$ Photobioreactor; SWw Secondary wastewater; FPBR $\mathrm{B}_{\mathrm{B}}$ Flat-Plate Photobioreactor; MZM Modified Zarrouk medium; $\mathrm{EFPBR}_{\mathrm{B}}$ Erlenmeyer flask Photobioreactor; $\mathrm{CPBR}_{\mathrm{C}}$ Cylindrical/column Photobioreactor; $\mathrm{BAPBR}_{\mathrm{C}}$ Bench-scale airlift photobioreactor; SYWw Synthetic wastewater; AA -SDCG - BC $\mathrm{B}_{\mathrm{B}}$ Air agitated - Sintered disk chromatographic glass bubble column-; $-\mathrm{CF}$ Complex fertilizer. Symbols: $R c=$ $\mathrm{CO}_{2}$ fixation rate estimated from Chisti ratio $\mathrm{CO}_{0.48} \mathrm{H}_{1 \cdot 831} \mathrm{~N}_{0.11} \mathrm{P}_{0.01} ; R_{X}=1.88 \times P_{X} ; P_{X}=$ biomass productivity estimated from $\Delta X / \Delta \mathrm{t}$; Subscripts: ${ }_{\mathrm{L}}$ lab-scale; batch; ${ }_{\mathrm{c}}$ continuous; ${ }_{\mathrm{s}}$ semi-continuous; $\mathrm{x}=$ Mixtrophic growth cultivation mode 